\title{
A study of Anti Thyroid Peroxidase (TPO) Antibody Titres in patients seeking treatment at a tertiary health care centre
}

\author{
Prajaya Shikar Shrestha ${ }^{1}$, Alark Devkota Rajouria' ${ }^{1}$, Dipak Malla ${ }^{1}$, Samyukta Bhattarai ${ }^{2}$, \\ Bharat Bahadur Amatya ${ }^{3}$, Manil Ratna Bajracharya ${ }^{1}$ \\ ${ }^{1}$ National Academy of Medical Sciences, Bir Hospital, Kathmandu, ${ }^{2}$ Volunteer Medical Doctor, \\ General Welfare Pratisthan, Kathmandu, ${ }^{3}$ NAMS, Trauma Centre, Kathmandu
}

\begin{abstract}
:
Background: One of the main cause of thyroid disease is autoimmune thyroid disease and anti thyroid peroxidase (TPO) antibodies is a major marker of the condition. There are very few studies in the country regarding the etiology of thyroid disorders and hence this study is being conducted for it. Methods: This is retrospective cross sectional study from 28 January 2019 to 29 July 2019 done at National Academy of Medical Sciences, Bir Hospital, Kathmandu . The laboratory serum sample data of all Anti TPO antibody results from patients seeking treatment at the instituition were analyzed for age and gender variation. Anti TPO antibody titre of equal or more than $34 \mathrm{IU} / \mathrm{ml}$ was considered as positive. Results: Out of 768 samples analysed for study, $79.9 \%$ were of women and $20.1 \%$ were of men. A total of $205(26.7 \%)$ were positive for anti TPO antibodies of which $83.4 \%$ were women and $16.6 \%$ were men . Women had more patients with anti TPO antibodies positive as compared men (27.9 vs $21.1 \%)$. Mean Anti TPO titre were also more in women as compared to men $(61.01 \mathrm{vs} 48.20 \mathrm{IU} / \mathrm{ml})$. Conclusions: About one fourth of the patients had siginificant titers of anti TPO antibodies suggestive of thyroid autoimmunity. Both prevalence of positive anti TPO antibody titres and the mean anti TPO antibody titre values were more in women as compared to men. Further well designed larger community studies are required.
\end{abstract}

Key Words: anti TPO antibodies, autoimmunity , Nepal , thyroid

\section{INTRODUCTION:}

Thyroid disorders are very common in the community. Causes of thyroid dysfunction include Graves Disease, multinodular goitre, solitory thyroid nodule, iodine related disorders, autoimmune thyroiditis, infilrative diseases etc. ${ }^{1}$ The most common cause of thyroid disorders worldwide is iodine deficiency, leading to goitre formation and hypothyroidism whereas in iodinereplete areas, most persons with thyroid disorders have autoimmune disease. ${ }^{2}$

In a large study done in Colorado US, the prevalence of increased TSH was $9.5 \%$ where as that of decreased TSH was $2.2 \%{ }^{3}$ A large multicentre

Corresponding Author:

Dr. Prajaya Shikar Shrestha, Endocrinologist, NAMS, Bir Hospital, Kathmandu, email: prajayashrestha@hotmail.com
Indian study showed that hypothyroidism was seen in approximately one in 10 adults in the study population. ${ }^{4}$

Patients with autoimmune thyroid disease as seen in Hashimoto's thyroiditis, Graves Disease and painless thyroiditis often have autoimmune activity against thyroid peroxidase (TPO) resulting in positive test in Anti TPO antibody titres. The test has its usefulness in determining the cause of primary hypothyroidism or euthyroid goitre is due to Hashimoto's thyroiditis. ${ }^{5}$

Anti TPO antibodies is especially helpful in the case of subclinical hypothyroidism in deciding initiation of treatment and the duration of treatment. In patients with subclinical hypothyroidism, presence of anti TPO antibodies is associated with an increased risk of developing overt hypothyroidism. ${ }^{1,6}$ 
It also has importance in management decisions in cases of hypothyroidism with pregnancy. In a study done by Singh A et al, thyroid antibodies proved to be a useful marker for identifying women at risk for clinical miscarriage.$^{7}$ Similarly a study from Harayana, India showed that TPO antibody positivity even in women with euythroid status are associated with adverse pregnancy outcomes such as miscarriage and preterm delivery. ${ }^{8}$

Immune cells , anti Thyroid antibodies and cytokines all may have a role in the pathogenesis of autoimmune thyroid disease. The demonstration of immune cells and anti-thyroid antibodies within the thyroid gland, and the determination of the levels of cytokines in peripheral blood, sheds information of their involvement in the development of autoimmune thyroid disorders. ${ }^{9}$ A Study done by Chivato et al suggest that TPO maybe a target for cytotoxic attacks. ${ }^{10}$ The ongoing progressive destruction of thyroid follicular tissue results in hypothyroidism. ${ }^{11}$ There are very few studies of finding the cause of thyroid disorders in the country and this study provides valuable insight into the prevalence of Hashimoto's Disease as one of the cause. Further research has also been recommended by some authors to assess the possibility of changing disease patterns of autoimmune thyroid disease as opposed to simple changes in diagnostic thresholds. ${ }^{12}$

\section{MATERIAL AND METHODS}

This is retrospective cross sectional study done at National Academy of Medical Sciences, Bir Hospital, Kathmandu. The laboratory serum sample data of all Anti TPO antibody results from the period of 28 January 2019 to 29 July 2019 duration were analysed. Laboratory testing of blood serum samples that had been done for Anti TPO antibodies in patients visiting for treatment were analysed for age, gender variation. Almost all of the patients in the test are known to have thyroid dysfunction of some magnitude and are sent from the Diabetes and Endocrinology unit at Bir Hospital for testing. Regarding investigations, generally anti TPO antibodies are done those with raised thyroid stimulating hormone (TSH) whereas nuclear imaging, TSH receptor antibodies are done in cases with low TSH values depending upon clinical scenario and necessity. The Anti TPO antibody test was done with high sensitive Anti TPO ELISA Kit from Epitope Diagnostics, Inc which measures high sensitivity of human anti TPO antibody IgG . A cut off point of equal or more than $35 \mathrm{IU} / \mathrm{ml}$ were considered as being positive for anti TPO antibodies. Patients who had thyroid disorders and had done anti TPO antibodies test before the study period or those who had done antibody test from some other hospital or health care centres were excluded from the study. Data analysis was done using SPSS software program.

\section{RESULTS}

There were a total of 768 patient samples analysed for the study out of which 614 (79.9\%) were female patients and $154(20.1 \%)$ were male patients.

Table 1. Age variation among patients

\begin{tabular}{|l|l|l|l|}
\hline Group & Mean & Age (in years) & Standard Deviations \\
\hline Total N=768 & 39.16 & 14.55 & \\
\hline Male patients N =154 & 45.35 & 16.49 & \\
\hline Female patients N=614 & 37.61 & 13.60 & \\
\hline Anti TPO ab positive Male pateints N=34 & 41.29 & 16.23 & \\
\hline Anti TPO ab positive Female pateints N=171 & 37.50 & 11.89 & \\
\hline
\end{tabular}


Anti TPO antibodies were positive in $205(26.7 \%)$ out of 768 patients implying that approximately one fourth of the patients had thyroid autoimmunity markers. Out of 205 total patients 171 ( $83.4 \%$ ) were women and 34( 16.6\%) were men as shown in Table 1.

Table 2. Anti TPO Titre variation among patients

\begin{tabular}{|l|l|l|}
\hline Group & IU/ml & Standard Deviations \\
\hline Total N=768 & 58.44 & 102.44 \\
\hline Male patients N =154 & 48.20 & 93.75 \\
\hline Female patients N=614 & 61.01 & 103.93 \\
\hline Anti TPO ab positive Male pateints N= 34 & 182.70 & 129.38 \\
\hline Anti TPO ab positive Female pateints N=171 & 189.94 & 125.26 \\
\hline
\end{tabular}

From a total of 614 females patients , 171 patients (27.9\%) were Anti TPO antibodies positive as compared to $34(22.1 \%)$ males from a total male sample of 154 . This shows that females had slightly more possible thyroid autoimmunity as compared to males. In general, Anti TPO antibodies titre were higher in females $(61.01 \mathrm{IU} / \mathrm{ml})$ as compared to males $(48.20 \mathrm{IU} / \mathrm{ml})$ as shown in Table 2.

Table 3. Anti TPO antibodies in different age groups

\begin{tabular}{|l|l|l|l|l|}
\hline $\begin{array}{l}\text { Age Group } \\
\text { (years) }\end{array}$ & $\begin{array}{l}\text { Total number } \\
\text { of cases }\end{array}$ & $\begin{array}{l}\text { Anti TPO } \\
\text { Antibody negative }\end{array}$ & $\begin{array}{l}\text { Anti TPO } \\
\text { Antibody Positive }\end{array}$ & $\begin{array}{l}\text { Mean Anti TPO } \\
\text { antibody titre (IU/ml) }\end{array}$ \\
\hline Less than 25 & 107 & $74(69.2 \%)$ & $33(30.8 \%)$ & 65.7907 \\
\hline $25-34$ & 235 & $182(77.4 \%)$ & $53(22.6 \%)$ & 49.6736 \\
\hline $35-44$ & 157 & $109(69.4 \%)$ & $48(30.6 \%)$ & 38.83 \\
\hline $45-54$ & 143 & $96(67.1 \%)$ & $47(32.9 \%)$ & 64.7189 \\
\hline $55-64$ & 80 & $60(75.0 \%)$ & $20(25.0 \%)$ & 50.8738 \\
\hline 65 or more & 46 & $42(91.3 \%)$ & $4(8.7 \%)$ & 26.4652 \\
\hline
\end{tabular}

From Table 3 it is seen that prevalence of antibodies in positive titres are mostly in similar proportions ranging around $20-30 \%$ in each group except for the age group more than 65 years where it is about $4 \%$ only. Anti TPO antibody titres are highest in the less than 25 years age group where as it is lowest in the age 35-44 years group. The highest number of the patients being tested belonged to the reproductive age group ie. 25-34 years , probably as a concern for menstrual irregulaity, excess weight gain concerns and fertility issues etc. Anti TPO antibodies positivity were most prevalent in the age group $45-54$ years.

\section{DISCUSSIONS}

Autoimmune thyroid disease is one of the common organ-specific autoimmune disorders. 3 It occurs because of complex interactions between genetics and environment.$^{13}$

In our study about one fourth of the patients that underwent the test had positive antibody titres which is a marker for autoimmune thyroid disorders. Similar to our study, in a study done by Unikrisnan et al study , Anti - TPO antibodies suggesting autoimmunity were detected in $21.85 \%$ patients. ${ }^{4}$ However a study from Kerala, India had a higher prevalence on anti TPO antibodies with about $46 \%$ among patients having thyroid dysfunction. ${ }^{14}$ In a study done in Delhi, the detection of significant titres of anti TPO antibodies were lower than that seen in our study being about $13 \% .{ }^{15}$

In studies in which no cytological testing done, 
among those who were negative for anti-TPO antibodies, there is a possibility of some of them would still have a cytological evidence of autoimmune destruction. ${ }^{16}$

In our study also females were more affected than males and the possible involvement of autoimmunity is also seen more in females. This is consistent with the findings from other studies. The mean anti TPO titre was also higher in women as compared to men in our study. Similarly Unnikrishnan et al. have reported higher prevalence of anti-TPO antibodies in females than in males in eight cities of India. ${ }^{4}$ Hollowell et al. while conducting United States national health and nutrition examination survey determined that prevalence of both anti-TPO is higher in females . ${ }^{17}$ This was also seen in a study done in subclinical hypothyroid patients by Atluri S et al. ${ }^{18}$

In a study done in Kerala by Sindhu P et al with a study population comprising of women of reproductive age group, maximum number of anti TPO antibodies positive women were in the age group 45-49 years of age however the mean value was highest in the 35-44 years age group. ${ }^{19}$ In a study done by Atluri S and team, anti TPO antibodies were more prevalent in the 20-40 years group . ${ }^{18}$ In our study, highest number of antibody positivity was seen in the 45-54 years age group however the highest anti TPO antibody titre mean value was in the age group less than 25 years group. There is referral bias in the our study as the patients have to come to a tertiary care centre seeking treatment and hence the results cannot be extrapolated as community data.

As this is a retrospective analysis of the lab reports only, due to unknown history of medication and their possible impact on the thyroid function reports, the Anti TPO reports have not been correlated with the thyroid function status. Although this is a major limitation of the study, because of very little data available in the country in this field, the research does provide useful information regarding the prevalence of autoimmune thyroid conditions and may help to provide a basis for future studies.

Future well designed studies should involve normal population for controls, thyroid function status, testing of treatment naïve thyroid disorders patients, testing of anti TSH receptor antibodies, testing for iodine deficeincy, thyroid ultrasonography, nuclear scan tests and for possible fine needle aspiration cytology (FNAC) in selected patients.

\section{CONCLUSIONS}

About one fourth of the patients had siginificant titers of anti TPO antibodies suggestive of thyroid autoimmunity. Positive anti TPO antibodies titre cases and the mean anti TPO titres were are also more in women as compared to men. Further well designed larger community studies are required to have a more clear picture of the current situation.

\section{Reference:}

1 MWJ Strachan, JDC Newell-Price in Chapter Endocrinology. Ralston SH, Penman ID, Strachan MWJ , Hobson RP Eds .Davidson's principles and Practice of Medicine.23rd Edition . New Delhi .Elsevier. 2018; 629-89.

2 Vanderpump MPJ. The epidemiology of thyroid disease. British Medical Bulletin: September $2011 ; 99$ (1) : 39-51

3 Canaris GJ, Manowitz NR, Mayor G, Ridgway EC. The Colorado thyroid disease prevalence study. Arch Intern Med 2000; 160:526-34.

4 Unnikrishnan AG, Kalra S, Sahay RK et al.Prevalence of hypothyroidism in adults: an epidemiological study in eight cities of India. Indian Journal of Endocrinology and Metabolism. 2013; 17 (4) : 647-52

5 Clutter WE in chapter Evaluation of thyroid Function. Baranski TJ, Clutter WE, McGill JB Eds . Endocrinology Subspeciality Consult. 3RD Edition. New Delhi .Wolters KluwerLippincott Williams Wilkins. 2016 ; 40-8

6 Vanderpump MP, Tunbridge WM, French $\mathrm{JM}$, et al. The incidence of thyroid disorders in the community: a twenty-year follow-up of the Whickham Survey. Clin Endocrinol 1995;43:55-68. 
7 Singh A, Dantas ZN, Stone NC, Asch RH. Presence of thyroid antibodies in early reproductive failure: biochemical versus clinical pregnancies. Fertil and Steril. 1995;63: 277-81.

8 Rajput R, Yadav T, Seth S, Nanda S . Prevalence of thyroid peroxidase antibody and pregnancy outcome in euthyroid autoimmune positive pregnant women from a tertiary care center in Haryana. Indian $\mathrm{J}$ Endocr Metab .2017; 21:577-80

9 Mikoś H,Mikoś M, Obara-Moszyńska M, Niedziela $M$.The role of the immune system and cytokines involved in the pathogenesis of autoimmune thyroid disease (AITD) .Endokrynologia Polska.2014; 65: 150-55.

10 Chiovato L, Bassi P, Santini F, Mammoli C, Lapi $\mathrm{P}$, Carayon $\mathrm{P}$ et al. Antibodies producing complement-mediated thyroid cytotoxicity in patients with atrophic or goitrous autoimmune thyroiditis. J Clin Endocrinol Metab .1993;77: 1700-5.

11 Holt RIG , Hanley NA in the Thyroid Gland .Essential Endocrinology and Diabetes. West Sussex . Blackwell Publishing limited. 2012; 165-89

12 McLeod DS, Cooper DS .The incidence and prevalence of thyroid autoimmunity. Endocrine. 2012 Oct; 42(2):252-65.

13 Swain M, Swain T, Kumar MB. Autoimmune thyroid disorders-an update. Indian $\mathrm{J}$ Clin Biochem 2005; 20:9-17

14 Usha Menon V, Sundaram KR, Unnikrishnan AG, Jayakumar RV, Nair V, Kumar H. High prevalence of undetected thyroid disorders in an iodine sufficient adult south Indian population.J Indian Med Assoc. 2009 Feb; 107(2):72-7

15 Marwaha RK, Tandon N, Ganie MA, Kanwar R, Sastry A, Garg MK, Bhadra K, Singh S. Status of thyroid function in Indian adults: two decades after universal salt iodization. J Assoc Physicians India. 2012 Apr; 60: 32-6

16 Jeena EJ , Malathi M, Sudeep K . A hospital based study of anti TPO titre in patients with thyroid disease. Muller J Med Sci Res. 2013 ;4:74-7

17 Hollowell JG, Staehling NW, Flanders WD et al. Serum TSH, T4, and Thyroid Antibodies in the United States Population (1988 to 1994): National Health and Nutrition Examination Survey (NHANES III). The Journal of Clinical Endocrinology \& Metabolism. 2002; 87 (2) 489-99

18 Atluri S, Boppana R, Goel A, Yalamanchi A, Biswas A, Shivaprasad C. Prevalence of Elevated Anti-Thyroid Peroxidase Antibodies in Subclinical Hypothyroidism. IJCMR March 2018 ; 5 (3) : C1-4

19 Sindhu PS, Pushpalatha M, Anil P. Antithyroid peroxidase antibody prevalence in reproductive age group females- a study from Central Kerala, India

India J. Evid . Based Med. Health. 2017 ; 4 (23).1336-40 